\title{
Revisiting the Role of Membrane ATPases (P-Type) in Metal-Ligand Homeostasis of Epidermal Cells
}

\author{
Petukhov VI* \\ Baltic International Academy, Riga, Latvia \\ *Corresponding author: Petukhov VI, Baltic International Academy, Riga, Latvia
}

\section{ARTICLE INFO} \\ Received: 慧 July 22, 2019 \\ Published: 慧 July 26, 2019 \\ Citation: Petukhov VI. Revisiting the \\ Role of Membrane ATPases (P-Type) in \\ Metal-Ligand Homeostasis of Epidermal \\ Cells. Biomed J Sci \& Tech Res 20(1)-2019. \\ BJSTR. MS.ID.003397.
}

\begin{abstract}
The present article comments on the results of hair spectrometry in pregnant and 9-month-old babies born to these women published in the Reproductive Toxicology journal (2018) [1]. The author of this article gives a different explanation of the data obtained by the aforesaid study in view of the idea of metal-ligand homeostasis in the epidermis as a self-organized criticality phenomenon.
\end{abstract}

\section{Introduction}

The reason for writing this comment was the recent publication by A.V. Skalny et al. "Toxicological and nutritional status of trace elements in hair of women with in vitro fertilization (IVF) pregnancy and their 9-month-old children" in the Reproductive Toxicology Journal 2018. Using inductively coupled plasma massspectrometry in dynamic reaction cell mode (ICP-DRC-MS) at NexION 300D (PerkinElmer Inc., CT, USA, the authors analyzed the content of chemical elements in the hair of pregnant women (in the III trimester) and their 9-month-old children. Of particular interest is the comparative analysis (mothers vs newborns) of the content of such metals as sodium $(\mathrm{Na})$, potassium $(\mathrm{K})$, calcium $(\mathrm{Ca})$, aluminum ( $\mathrm{Al}$ ), cadmium (Cd), iron ( $\mathrm{Fe}$ ), chromium (Cr), copper $(\mathrm{Cu})$, lithium $(\mathrm{Li})$, lead $(\mathrm{Pb})$, vanadium $(\mathrm{V})$ and zinc $(\mathrm{Zn})$ in the epidermis. Although the authors did not draw much attention to the comparison, it would be unjustifiable to ignore it. The fact is that the concentrations of these metals, measured in the same way (atomic emission spectrometry) and in the same bio substrate (hair), were the subject matter of the comparative analysis in our previous studies in healthy individuals and liquidators of the Chernobyl accident $[2,3]$. The spectrometry results are shown in Table 1 . The content of metals in the epidermis among the liquidators of the accident significantly differed from the control group (Table 1). For convenience, the above differences can be presented as follows (indicating their direction ( $\uparrow$ - excess, $\downarrow$ - understatement):
$\mathrm{K}(\uparrow), \mathrm{Na}(\uparrow), \mathrm{Ca}_{\mathrm{fem}}(\downarrow), \mathrm{V}(\uparrow), \operatorname{Zn}(\downarrow), \operatorname{Cu}(\downarrow), \operatorname{Cd}(\uparrow), \operatorname{Fe}(\uparrow), \operatorname{Al}(\uparrow), \operatorname{Cr}(\uparrow)$, $\operatorname{Pb}(\uparrow), \operatorname{Li}(\uparrow)$.

The observed shifts in the metal-ligand homeostasis (MLH) of the epidermis in their direction are practically identical (except Fe) to the hair, spectrometry results of the authors referred to in [1] Table 2. It should be noted that the concentration values of metals in Table 1 are presented as mean with confidence intervals (bootstrap-method), and in Table 2 - as median. This, to a certain extent, explains the discrepancy between the compared values but does not affect the direction of the existing shifts in the MLH. When comparing the spectrometry data (Tables $1 \& 2$ ), it is not difficult to see that the quantitative shifts in MLH of the epidermis are almost identical in their direction for all metals (except Fe) in accident liquidators (compared to control) and in nine-month-old babies (compared to pregnant):

$\mathrm{K}(\uparrow), \operatorname{Na}(\uparrow), \operatorname{Ca}(\downarrow), \mathrm{V}(\uparrow), \operatorname{Zn}(\downarrow), \operatorname{Cu}(\downarrow), \operatorname{Cd}(\uparrow), \operatorname{Al}(\uparrow), \operatorname{Cr}(\uparrow), \operatorname{Pb}(\uparrow)$, Li (个)

\section{The Following Two Key Issues Need to Be Discussed}

a) What is common between the two groups (infants and liquidators of the Chernobyl accident)?

b) How the conjugacy (synchronism) of the observed shifts can be explained (at least presumably)? It is known that 
reactive oxygen (ROS) and nitrogen (RNS) species are activators of membrane ATPases (P-type) driving metal traffic due to oxidative modification and/or nitrosylation of SH-groups in their protein molecule. Therefore, increased production of ROS and RNS under conditions of oxidative and/or nitrosative stress will inevitably stimulate the operation of these ATP-dependent pumps.

Information on the presence of oxidative and nitrosative stress among the liquidators of the Chernobyl accident has already been published $[4,5]$. Reports on the given topic relating to young children are very few. There is sporadic evidence of a pro-oxidative shift in the redox status of children aged 7 to 11 years [6]. The probability of increased production of ROS is very likely both at an early age and in old age. It was during these periods (for various reasons) that the number of mitochondria, the main producers of ATP, was reduced. Therefore it cannot be ruled out that it is the increased production of ROS and RNS (oxidative/nitrosative stress) that is able to compensate for the lack of ATP due to a greater influx of other convertible energy currency into the cell, $\mathrm{Na}^{+}$ions, which becomes possible under these conditions with intensive $\mathrm{Na}^{+} / \mathrm{K}^{+}$ ATPase activity. The probability of such events may be indicated by our observations, in which the age-related dynamics of $\mathrm{Na}$ and $\mathrm{K}$ in the epidermis (spectrometry data) in 10297 healthy individuals were studied [2]. Two periods of a significant increase in the level of these metals in bio substrate were found: the first between 2 and 9 years of age; the second is from 60 to 85 years. Unfortunately, the quantitative shifts of other metals were not analyzed, although in children aged 2-9 years they could be identical to those given by the authors of the study in question [1] Table 2.

Thus, an increased production of ROS and RNS (oxidative/ nitrosative stress) most likely becomes a common cause of the observed shifts in the MLH of the epidermis in Chernobyl liquidators and young children, although laboratory confirmation of this possibility has been obtained only from emergency workers $[4,5]$. Further, the mechanism of coordinated (synchronous) nature of the observed shifts in the MLH of the epidermis can be explained as follows. From the point of view of bioenergetics, a living cell is an open dynamic system, on whose border (plasma membrane) there is a

Table 1: Content of metals in epidermal cells of liquidators of the Chernobyl accident and healthy individuals [3]. Mean values are shown in bold; normal fonts show confidence interval (bootstrap-method); asterisks show statistical significance of differences: ${ }^{*}$ ) $\mathrm{p}$ $\left.<0.001 ;{ }^{* *}\right) \mathrm{p}<0.05$.

\begin{tabular}{|c|c|c|}
\hline Metals & Healthy individuals $\mathbf{( n = 9 4 7 )} \mathbf{\mu g} / \mathbf{g}$ & Liquidators of the Chernobyl accident $(\mathbf{n}=\mathbf{9 5 4}) \boldsymbol{\mu g} / \mathbf{g}$ \\
\hline $\mathrm{K}$ & $277.4<\mathbf{3 1 7 . 7}<361,1$ & $365.8<\mathbf{3 9 4 . 8}<422.4^{*}$ \\
\hline $\mathrm{Na}$ & $427.9<\mathbf{4 8 0 . 9}<542.9$ & $757.5<\mathbf{8 2 2 . 3}<892.4^{*}$ \\
\hline $\mathrm{Ca}_{(\text {female) }}$ & $1348.1<\mathbf{1 4 3 9 . 6}<1528.4$ & $832.0<\mathbf{9 2 7 . 4}<1032.8^{*}$ \\
\hline $\mathrm{V}_{(\mathrm{female})}$ & $0.058<\mathbf{0 . 0 6}<0.07$ & $0.10<0.12<0.13^{*}$ \\
\hline $\mathrm{V}_{(\text {male })}$ & $0.08<\mathbf{0 . 0 9}<0.1$ & $0.11<\mathbf{0 . 1 1 6}<0,12^{*}$ \\
\hline $\mathrm{Zn}$ & $181.5<\mathbf{1 8 5 . 2}<189.3$ & $162.5<\mathbf{1 6 5 . 8}<169^{*}$ \\
\hline $\mathrm{Cu}$ & $19.06<\mathbf{2 0 . 7}<22.3$ & $10.6<\mathbf{1 0 . 9 9}<11.4^{*}$ \\
\hline $\mathrm{Cd}$ & $0.04<\mathbf{0 . 0 5}<0.06$ & $0.2<\mathbf{0 . 2 5}<0.3^{*}$ \\
\hline $\mathrm{Fe}$ & $19.3<\mathbf{2 1 . 0 7}<23.1$ & $22.4<\mathbf{2 3 . 7}<25.07^{* *}$ \\
\hline
\end{tabular}

Copyright@ Petukhov VI | Biomed J Sci \& Tech Res | BJSTR. MS.ID.003397.

constant exchange of energy with its environment. Such an energy exchange is most indicative of the transmembrane traffic of metals, which requires not only ATP energy but also the energy potential of the metals themselves (for example, sodium). The laws of self-organized criticality (SC), which seem to have a wide (but insufficiently studied) distribution in nature, can manifest themselves under these conditions. According to these laws, the membrane pumps in charge of metal traffic (being oscillators) form a single oscillator system capable of critical self-organization or a transition to a critical state. For such a transition, a sufficient "density" (number) of activated membrane pumps is necessary. This is much easier to achieve with increased production of activator molecules -ROS and RNS (oxidative and/or nitrosative stress). From the standpoint of the SC theory, the synchronization is a special case of criticality. Therefore, the critical (synchronous) operation of $\mathrm{Na}^{+} / \mathrm{K}^{+}$-ATPase can be indicated by a reliable $(\mathrm{p}<0.05)$ and stable (independent of the sample size) linear correlation between the $\mathrm{Na}$ and $\mathrm{K}$ in healthy individuals $(r=0.6)$ and emergency responders $(r=0.7)$ [2].

Besides, the negative linear correlation between $\mathrm{K}$ and $\mathrm{Zn}$ revealed by us ( $\mathrm{r}_{\mathrm{K}-\mathrm{Zn}}=-0.28$ in healthy people and $\mathrm{r}_{\mathrm{K}-\mathrm{Zn}}=-0.42$ in liquidators of the accident) also points to the same. Interestingly, the group of healthy individuals was heterogeneous in $\mathrm{r}_{\mathrm{K}-\mathrm{Zn}}$ (in $55.2 \% \mathrm{r}_{\mathrm{K}-\mathrm{Zn}}=-0.22$; in $26.7 \% \mathrm{r}_{\mathrm{K}-\mathrm{Zn}}=-0.01$ and in $18.1 \% \mathrm{r}_{\mathrm{K}-\mathrm{Zn}}=$ $-0.43)$. This gives grounds to assume the presence of oxidative and/ or nitrosative stress of not radiation origin in $18.1 \%$ of "practically healthy" individuals. If the quantitative shifts in the MLH of the epidermis really depend on the synchronous operation of the membrane pumps, then the strengthening of the K-Zn bond should be accompanied by the appearance of conjugate (of the same type) quantitative changes in the MLH. The results of the studies suggest this statement (Table 3) [3]. Mean values are shown in bold; normal fonts show confidence interval (bootstrap-method); asterisks show statistical significance of differences: $\left.{ }^{*}\right) \mathrm{p}<0.001$; ${ }^{* *}$ ) $\mathrm{p}<0.05$. Shifts in the MLH of the epidermis in healthy subjects with a noticeable $\mathrm{K}-\mathrm{Zn}$ bond $\left(\mathrm{r}_{\mathrm{K}-\mathrm{Zn}}=-0.43 ; \mathrm{p}<0.05\right)$ (Table 3 ) have the same direction as in infants, with the exception of Fe (Table 2), as well as among the liquidators of the accident Table 1. Alternatively, in a symbolic notation: $\mathrm{p}$

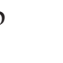




\begin{tabular}{|c|c|c|}
\hline $\mathrm{Al}$ & $8.1<\mathbf{8 . 8}<9.5$ & $19.3<\mathbf{2 0 . 1}<20.9^{*}$ \\
\hline $\mathrm{Cr}$ & $0.48<\mathbf{0 . 5 1}<0.54$ & $0.85<\mathbf{0 . 9}<0.92^{*}$ \\
\hline $\mathrm{Pb}$ & $1.04<\mathbf{1 . 1}<1.27$ & $1.5<\mathbf{1 . 8}<2.2^{*}$ \\
\hline $\mathrm{Li}$ & $0.03<\mathbf{0 . 0 4}<0.05$ & $0.05<\mathbf{0 . 0 6}<0.062^{*}$ \\
\hline
\end{tabular}

Table 2: Metal content in the hair of pregnant women and their 9-month-old babies [1].

\begin{tabular}{|c|c|c|}
\hline Metals & $\begin{array}{c}\text { Pregnant Women } \\
(\mathbf{n}=\mathbf{1 5 8}) \boldsymbol{\mu g} / \mathbf{g}\end{array}$ & $\begin{array}{c}\text { 9-Month-Old Babies } \\
(\mathbf{n}=\mathbf{1 5 8}) \boldsymbol{\mu g} / \mathbf{g}\end{array}$ \\
\hline $\mathbf{K}$ & $\mathbf{1 0 0 . 4}(46.0-191.1)$ & $\mathbf{9 8 7 . 7}(365.0-1621)$ \\
\hline $\mathbf{N a}$ & $\mathbf{8 2 . 3 8}(47.02-143.0)$ & $\mathbf{3 3 4 . 4}(163.1-607.3)$ \\
\hline $\mathbf{C a}$ & $\mathbf{1 9 4 1}(1144-2992)$ & $\mathbf{3 5 1 . 2}(259.7-523.9)$ \\
\hline $\mathbf{V}$ & $\mathbf{0 . 0 0 9}(0.005-0.018)$ & $\mathbf{0 . 0 2}(0.012-0.044)$ \\
\hline $\mathbf{Z n}$ & $\mathbf{2 2 9 . 3}(192.3-303.6)$ & $\mathbf{7 5 . 3 4}(46.53-119.88)$ \\
\hline $\mathbf{C u}$ & $\mathbf{1 5 . 6}(10.8-26.54)$ & $\mathbf{1 0 . 7 9}(8.51-13.67)$ \\
\hline $\mathbf{C d}$ & $\mathbf{0 . 0 0 9}(0.004-0.016)$ & $\mathbf{0 . 0 4 3}(0.021-0.072)$ \\
\hline $\mathbf{F}$ & $\mathbf{1 8 . 4 6}(11.32-30.18)$ & $\mathbf{1 6 . 1 9}(11.71-24.15)$ \\
\hline $\mathbf{A l}$ & $\mathbf{3 . 4 8 5}(2,156-5,629)$ & $\mathbf{1 0 . 8 4}(6.19-18.58)$ \\
\hline $\mathbf{C r}$ & $\mathbf{0 . 0 8 3}(0.044-0,162)$ & $\mathbf{0 . 1 9 9}(0.134-0.333)$ \\
\hline $\mathbf{P b}$ & $\mathbf{0 . 3 3 4}(0.205-0.60)$ & $\mathbf{1 . 2 8 4}(0.677-2.161)$ \\
\hline $\mathbf{L i}$ & $\mathbf{0 . 0 0 8}(0.004-0.013)$ & $\mathbf{0 . 0 1 9}(0.011-0.037)$ \\
\hline
\end{tabular}

Table 3: Content of metals in healthy subjects with different values of $\mathrm{r}_{\mathrm{K}-\mathrm{Zn}}$ [3].

\begin{tabular}{|c|c|c|}
\hline \multicolumn{3}{|c|}{ Healthy subjects $(\mathrm{n}=947) \mu \mathrm{g} / \mathrm{g}$} \\
\hline Metals & $r_{K-Z n}=-0.01(p<0.05) n=253$ & $r_{K-Z n}=-0.43(p<0.05) n=171$ \\
\hline $\mathrm{K}$ & $82.6<\mathbf{1 2 7}<181.9$ & $715.3<\mathbf{8 9 4}<1094.8^{*}$ \\
\hline $\mathrm{Na}$ & $159.7<\mathbf{1 9 7 . 8}<245.4$ & $1020.6<\mathbf{1 2 3 3 . 9}<1506.5^{*}$ \\
\hline $\mathrm{Ca}_{\text {female }}$ & $1494.6<\mathbf{1 6 2 7 . 8}<1770.8$ & $788.8<946.8<1101.1^{*}$ \\
\hline$V_{\text {female }}$ & $0.05<\mathbf{0 , 0 6}<0.07$ & $0.08<0.09<0.11^{*}$ \\
\hline $\mathrm{V}_{\text {male }}$ & $0.05<\mathbf{0 . 0 6}<0.07$ & $0.09<\mathbf{0 . 1 1}<0.13^{*}$ \\
\hline $\mathrm{Zn}$ & $196.0<\mathbf{2 0 4 . 3}<213.5$ & $143.2<\mathbf{1 5 0 . 7}<158.3^{*}$ \\
\hline $\mathrm{Cu}$ & $18.6<21<23.5$ & $14.3<\mathbf{1 6}<18.2^{*}$ \\
\hline $\mathrm{Cd}$ & $0.027<\mathbf{0 . 0 3}<0.04$ & $0.05<\mathbf{0 . 0 6}<0.08^{*}$ \\
\hline $\mathrm{Fe}$ & $15.0<\mathbf{1 7 . 8}<21.5$ & $20.0<\mathbf{2 2 . 5}<24.9^{* *}$ \\
\hline $\mathrm{Al}$ & $4.3<5.2<6.2$ & $10.8<\mathbf{1 2 . 3}<14.2^{*}$ \\
\hline $\mathrm{Cr}$ & $0.35<\mathbf{0 . 3 9}<0.42$ & $0.62<0.72<0.83^{*}$ \\
\hline $\mathrm{Pb}$ & $0.68<0.95<1.3$ & $1.1<\mathbf{1 . 4}<1.6^{* *}$ \\
\hline $\mathrm{Li}$ & $0.02<\mathbf{0 . 0 2 3}<0.03$ & $0.046<\mathbf{0 . 0 5}<0.06^{*}$ \\
\hline
\end{tabular}

$\mathrm{K}(\uparrow), \mathrm{Na}(\uparrow), \mathrm{Ca}_{\mathrm{fem}}(\downarrow), \mathrm{V}(\uparrow), \operatorname{Zn}(\downarrow), \operatorname{Cu}(\downarrow), \operatorname{Cd}(\uparrow), \operatorname{Fe}(\uparrow), \operatorname{Al}(\uparrow), \operatorname{Cr}(\uparrow)$ $\operatorname{Pb}(\uparrow), \operatorname{Li}(\uparrow)$

Another confirmation of criticality (synchronization) of membrane ATPases (P-type) can be obtained by detecting a power-related relationship between the intracellular metal content and the number of epidermal cells. Unfortunately, the solution of this research task at the cellular level is fraught with serious methodological difficulties. However, using this approach at the level of the whole body (with hair spectrometry) allows you to avoid such problems. The fact is that the power function, by means of which the critical state is described mathematically, is fractal (independent of the scale of measurements). Therefore, the numerical patterns found at the cellular level will be similar to those at the level of individuals. It is also known that on a graph in a double logarithmic scale the power function takes the form of a straight line. Therefore, the detection of a straight line on the given graph indicating the existence of a power relation between the number of individuals and the level of metals in the epidermis (hair) may serve as yet another indication of the criticality (synchronization) of membrane ATPases (P-type). Graphic confirmations were obtained of the critical period in transmembrane traffic of $\mathrm{Na}, \mathrm{K}, \mathrm{Ca}$ [3] and other metals [7], which is indicative of the fact that the MLH in the epidermis belongs to SC-phenomena. 


\section{Conclusion}

In conclusion, I would like to emphasize that assessment of the MLH in the epidermis based on the results of hair spectrometry should include, as a minimum:

a) The idea of MLH in this bio substrate as a self-organized criticality phenomenon, which is necessary for an objective analysis of the observed shifts.

b) Rejection of the illusive judgment (based on hair spectrometry data only) about the metal "security" of the whole body.

\section{References}

1. Skalny AV, Tinkov AA, Bohan TG, Shabalovskaya MB, Terekhina O, et al. (2018) Toxicological and nutritional status of trace elements in hair of women with In Vitro Fertilization (IVF) pregnancy and their 9-monthold children. Reproductive Toxicol 82: 50-56.

ISSN: 2574-1241

DOI: 10.26717/BJSTR.2019.20.003397

Petukhov VI. Biomed J Sci \& Tech Res

cC) (P) This work is licensed under Creative

Submission Link: https://biomedres.us/submit-manuscript.php
2. Petukhov VI, Dmitriev EV, Kalvinsh I, Baumane LK h, Reste ED, et al. (2011) Metal-ligand homeostasis in epidermic cells of chernobyl accident liquidators. Vitamins \& Trace Elements 1(2): 1-8.

3. Petukhov VI, Dmitriev EV, Baumane LK h, Skalny AV, Lobanova Yu N (2016) Electrogenic metals in epidermis: Relationship with cell bioenergetics. Insights in Biomed 1(2): 9-14.

4. Kumerova AO, Lece AG, Skesters AP, Orlikov GA, Seleznev JV, et al. (2000) Antioxidant defense and trace elements imbalance on patients with postradiation syndrome. Biol Trace Element Res 77: 1-12.

5. Petukhov VI, Baumane LK, Reste ED, Zvagule TY, Romanova MA, et al. (2013) Diagnosis of nitrosative stress by quantitative EPR-spectroscopy of epidermal cells. Bull Exp Biol Med 154: 734-736.

6. Kolesnikova LI, Darenskaia MA, Grebenkina LA, Osipova EV, Dolgikh MI, et al. (2013) The state of the antioxidant status of children of different ages. Voprosy Pitaniya 4: 27-33.

7. Petukhov VI, Dmitriev EV, Baumane LK H, Skalny AV, Lobanova Yu N, et al. (2018) Some aspects of regulatory criteria for metal-ligand homeostasis in epidermal cells. Journal of Antioxidant Activity 1(3): 22-32.

$\begin{array}{ll}\text { BIOMEDICAL } & \text { Assets of Publishing with us } \\ \text { RESEARCHES } & \text { - Global archiving of articles } \\ & \text { - Immediate, unrestricted online access } \\ & \text { - Rigorous Peer Review Process } \\ \end{array}$

